\title{
FILSAFAT YOGA Ashtānga-yoga Menurut Yoga-Sūtras Pātañjali
}

\begin{abstract}
Matius Ali ${ }^{*}$
Abstract: What is Yoga? How is Self-realization achieved through Yoga? The great Sage Pātañjali (3rd Century B.C.) defined yoga in the Yoga-Sütras as "the restraint of the modifications of the mind" (yogaś-citta-vritti-nirodah). In his Yoga-Sūtras (196 sutras), Pātañjali systematically laid down the exact methods and techniques for attaining Self-realization through the Eight Limbs of Pātañjali's Yoga (Ashtānga-yoga). This system is commonly known as Räja-yoga (Royal yoga). This Eight Steps is the way to attain self-transcendence. It consists of yama, niyama, āsanas, prānāyāma, pratyāhāra, dhāranā, dhyāna and samädhi. This article will focus on Ashtannga-yoga in the practical and philosophical contexts. Other systems of yoga also use this Eight Steps, but each yoga may start from and emphasize different aspects of yoga. However all systems of yoga accept and practice the Eight Steps of yoga to achieve the final goal, that is liberation (kaivalya, moksha, mukti). Yoga also reconciles the six systems of Indian Philosophy (Shadh Darśana).
\end{abstract}

Keywords: Rāja-yoga (Royal yoga), Hatha-yoga (Hard yoga), Bhakti-yoga (Yoga of Devotion), Jñanna-yoga (Yoga of Knowledge), Ashtānga-yoga (Eight limbs of Yoga), Citta-vritti-nirodha (Restraint of modification of the mind), Purusha (Spirit), Prakriti (Matter), Iśvara-pranidhāna (Surrender to God), Moksha (Liberation).

\section{LATAR BELAKANG HISTORIS}

Teks suci tertua yang merujuk pada yoga adalah Rig-Weda, yang berasal dari sekitar tiga ribu tahun sebelum masehi (s.M.). Teks ini berisi kompilasi berbagai mantra, kidung, yang memiliki efek dan makna mistis.

* Matius Ali, Fakultas Film dan Televisi, Institut Kesenian Jakarta, Jl. Cikini Raya 73, Jakarta 10330.E-mail:perwathin@yahoo.com. 
Secara tradisional, pengetahuan awal yoga diturunkan secara lisan dan kemudian dicatat dalam bahasa Sanskerta. Selain Rig-Weda, kemudian ditambahkan tiga Weda lainnya yang berisi mantra, kidung dan liturgi. Teks-teks Weda ini dikumpulkan dalam "empat buku" (Samhitās) dan diselesaikan pada 1200 s.M.

Antara 1200-800 s.M., kasta Brāhmana mendudukkan diri mereka sebagai kasta pendeta yang mengatur serta melaksanakan tata ritual menurut kitab Weda. Pada masa ini, para sarjana Brähmana menyusun banyak literatur tentang ritual kurban dan dikenal sebagai kitab Brāhmana. Teks ini merupakan karya prosa yang ditambahkan pada keempat Weda. Sebagai contoh, teks Brāhmana Aitareya dan Kauśítaki termasuk dalam kelompok Rig-Weda, Śatapatha, dan Taittirìya termasuk kategori Yajur-Weda; dan Gopatha termasuk dalam Atharva-Weda. Teks Sāma-Weda memiliki delapan bagian Brāhmanas, dan dua teks paling populer adalah Pañcavimśa dan Shadvimśa. Teks-teks Brāhmanas ini ditulis untuk memberikan penjelasan rinci mengenai kata Weda. ${ }^{1}$

Masa Brāhmanas kemudian diteruskan oleh masa Upanishad (800500 s.M.). Kurun Upanishad ini merupakan masa keemasan bagi teologi dan filsafat India serta menghasilkan serangkaian teks suci yang dikenal sebagai Upanishads. Kata upanishad memiliki dua arti, pertama adalah "duduk di kaki sang Guru untuk mendapatkan pengetahuan" dan kedua adalah "menghilangkan kebodohan atau kegelapan batin sang murid melalui pengetahuan tentang Roh absolut."

Upanishad merupakan dialog filosofis antara para Rishi dan muridmurid mereka. Banyak teks Upanishads dimasukkan menjadi bagian dari teks Brāhmanas. Tujuan utama teks Upanishads adalah menjelaskan serta menyederhanakan bagian sisi mistis kitab Weda. Upanishads menekankan penemuan kembali sang Diri (Self). Pada awalnya, teks Upanishads hanya berjumlah seratus delapan, namun kemudian berkembang menjadi lebih dari dua ratus teks. ${ }^{2}$

Masa Upanishad kemudian diikuti oleh masa Epos (600-400 s.M.), yang menghasilkan dua teks utama, yakni Rāmāyana, Mahābhārata dan sekitar dua puluh teks Purānas. Teks Bhagavad-Gītā yang terkenal adalah bagian Parwa Bhisma dari kitab epos Mahābhārata. Teks Purāna yang paling terkenal adalah Bhāgavata-Purāna (Srimad-Bhāgavata), yang menggambarkan kehidupan Sri Krishna sebagai inkarnasi ilahi.

1 S. Rajarshi Muni, Yoga: The Ultimate Attainment (Mumbai: Jaico Publishing House, 2004), p. 20. Untuk Diagram keempat Weda, lihat Klaus K. Klostermaier, Hinduism: A Short Introduction (Oxford: Oneworld Publications, 2005), p. 17; lihat juga Jesuit Scholars, Religious Hinduism: A Presentation and Appraisal (Allahabad: St. Paul Publications, 1968), p. 32.

2 S. Rajarshi Muni, Yoga: The Ultimate Attainment, p. 21. 
Teks-teks Epos dan Purāna juga memiliki prinsip yoga seperti dalam teks yoga kuno, namun tercampur dengan data-data mitologis lainnya. ${ }^{3}$

Walaupun yoga memang sudah ada pada ribuan tahun sebelumnya, namun baru pada abad ke-3 s.M., seorang Rishi bernama Pātañjali menyusun sebuah teks berupa kompendium yoga yang dikenal sebagai Yoga-Sūtras (Aphorisms of Yoga). Pātañjali dianggap sebagai orang pertama yang mendudukkan metode serta teknik yang tepat untuk pencapaian yoga. Yoga-Sūtras dianggap sebagai karya terbesar di bidangnya. Pātāñjali mengumpulkan serta membagi secara sistematis semua teknik yoga yang sudah ada dalam tradisi klasik India. Pātāñjali mendudukkan yoga sebagai sebuah disiplin praktis, dengan memfokuskan diri pada "delapan aspek" atau "delapan ruas" yoga (Ashtānga-yoga): Tindakan moral (Yama), Disiplin diri (Niyama), Postur tubuh (Äsanas), Pengendalian napas (Prānāyāma), Pengendalian indera (Pratyāhāra), Konsentrasi (Dhāranā), Meditasi (Dhyāna) dan Kontemplasi, serta Kondisi Suprasadar (Samādhi). ${ }^{4}$

\section{DEFINISI YOGA}

Dalam khasanah yoga, definisi klasik Pātāñjali dalam Yoga-Sūtras masih tetap dipakai sebagai acuan. Definisi ini dijelaskan dalam YogaSūtras, bagian Samādhi Pada (I, 2): "yogaś-citta-vritti-nirodah," artinya "yoga adalah pengendalian modifikasi pikiran." ${ }^{5}$

Secara etimologis, kata yoga diturunkan dari kata yuj (Sanskerta), yoke (Inggris), yang berarti penyatuan (union). Yoga artinya penyatuan antara kesadaran individual (Jīvātman) dan kesadaran yang lebih transenden, lebih kekal dan ilahi (Paramātman). Menurut Panini, akar kata yuj memiliki tiga arti yang berbeda, yakni penyerapan, samādhi (yujyate), menghubungkan (yunakti), dan pengendalian (yojyanti). Makna kunci yang biasa dipakai adalah meditasi (dhyāna) dan penyatuan (yukti). Dalam Bhakti-yoga, yoga berarti penyatuan (sayujya) dengan Tuhan (Isvara). Dalam sistem Yoga, yoga berarti bahwa semua yang berevolusi akhirnya akan larut dan menyatu ke dalam keseimbangan prakriti, dan purusha akan terserap kembali dan terpisah ke dalam esensi pertamanya sendiri. $^{6}$

3 S. Rajarshi Muni, Yoga: The Ultimate Attainment, p. 22.

4 S. Rajarshi Muni, Yoga: The Ultimate Attainment, p. 23; juga "The Eight Steps of Ashtānga-Yoga" in Klaus K. Klostermaier, Hinduism: A Short Introduction, p. 100.

5 Sri Swami Satchidananda, The Yoga-Sütras of Pātañjali (Yogaville, Virginia: Integral Yoga Publications, 2007), p. 3; juga Shri Yogendra (Transl.), Yoga-Sūtra, p. 11; Bdk. Georg Feuerstein, The Yoga-Sütra of Pātañjali: A New Translation and Commentary (Folkestone, Kent: Dawson \& Sons Ltd., 1979), p. 26.

6 Yakub Masih, The Hindu Religious Thought (3000 B.C - 200 A.D.) (Delhi: Motilal Banarsidass, 1983), p. 139. 
Karena pikiran selalu melakukan pemisahan, manusia terpisah dari sumber penopang transendennya. Hidupnya adalah urusannya sendiri. Pikiran serta ide-idenya juga adalah sebagai ciptaan serta milik pikirannya; keberhasilan serta kegagalannya merupakan hasil usahanya sendiri. Pemisahan diri individu dari kesatuan alam semesta dan keabadian transenden menciptakan kebodohan atau kegelapan batin (avidya $).{ }^{7}$ Sejak kejatuhan Adam dari taman Firdaus, ia masih terus berada dalam pemisahan yang egoistis, tidak akan ada pemulihan dirinya yang tidak terbatas dan abadi. ${ }^{8}$

Perubahan kesadaran merupakan seluruh makna dari proses yoga. Yoga adalah sebuah proses, usaha, serta tindakan melalui mana manusia berusaha untuk mengatasi batas kesadaran mentalnya sehari-hari ke dalam suatu kesadaran lebih luhur. ${ }^{9}$ Semua yoga pada esensinya adalah peningkatan atau pendalaman kesadaran manusia, agar ia mampu mencapai sesuatu di luar kesadaran serta kodratnya yang biasa. Yoga adalah keterhubungan dengan kedalaman diri di dalam diri, ketinggian di atas dan keluasan di luar diri, sehingga kesadaran kita tidak diatur oleh kesadaran permukaan yang sehari-hari. ${ }^{10}$

Menurut Sri Aurobindo, kata yoga biasa dipakai untuk menunjukkan semua proses atau akibat dari proses yang membukakan suatu pengalaman, pengetahuan, dan kesadaran yang lebih luhur. Yoga mencakup semua disiplin psikis untuk masuk ke dalam suatu kondisi kesadaran spiritual; semua pendekatan sistematis yang mengarah pada Realitas batin atau Realitas tertinggi; semua perubahan kesadaran dari tahap normal ke tahap lebih luas, tinggi atau lebih dalam. ${ }^{11}$

Yoga menunjukkan pada kita rahasia sang Diri (Self) dan yang Ilahi (Divine). Yoga dapat memberikan kita pengetahuan, penglihatan, dan kehadiran Realitas imanen, kosmis, dan transenden. Jadi, melalui pintu yoga inilah kita dapat mengatasi kebodohan (avidyā) akan hakikat Diri

7 Avidyā (Sanskerta) atau Avijjā (Pāli), “ignorance (Inggris)," artinya "kebodohan," "kegelapan batin," tidak tahu kesunyataan, tidak bisa membedakan antara baik dan buruk. Lihat Panjika \& N. Perawira, Kamus Baru Buddha Dhamma, p. 45. Kesadaran separatif dan pikiran serta hidup yang egoistis. Ini terjadi karena gerak inteligensi kosmis yang memisahkan dirinya dari cahaya kesadaran Supramental (Supermind), sehingga kehilangan kebenaran sejati. Lihat M.P. Pandit, Dictionary of Sri Aurobindo's Yoga (Twin Lakes, WI: Lotus Light Publication, 2001), p. 113. Bdk. Oliver Leaman, Key Concepts in Eastern Philosophy (London \& New York: Routledge, 1999), p. 32, "avidyä" juga berarti "tidak berpengetahuan, tidak mengenal hakikat realitas."

8 Rishabhchand, The Integral Yoga of Sri Aurobindo (Pondicherry: Sri Aurobindo Memorial Fund Society, 1974), p. 2.

9 Rishabhchand, The Integral Yoga of Sri Aurobindo, p. 343.

10 Sri Aurobindo, Essays Divine and Human (Pondicherry: Sri Aurobindo Ashram, 1996), pp. 343-344.

11 Sri Aurobindo, Essays Divine and Human, p. 345. 
sejati dan menuju ke kepenuhan cahaya akan pengetahuan tentang sang Diri. ${ }^{12}$ Melalui yoga kita dapat melewati dari manusia fenomenal ke manusia sejati; dari kesadaran permukaan yang tampak ke kesadaran Diri yang sejati (Ātman). Melalui yoga kita akan disadarkan bahwa Diri sejati $(\bar{A}$ tman $)$ dan Diri kosmis adalah satu (Brahman). ${ }^{13}$

\section{TUJUAN YOGA}

Tujuan sistem Rāja-yoga Pātañjali adalah untuk mencapai pembebas-an (liberation) melalui konsentrasi (dhāranā) dan samādhi. Istilah teknis untuk pencapaian ini adalah pembebasan (kaivalya). Kata kaivalya adalah identik dengan keilahian (divinity), karena hal-hal material tergantung pada penyebab lain atau daya-daya luar, sehingga tidak dapat menggerakkan diri sendiri. ${ }^{14}$ Kata ini juga dipakai oleh Pātañjali sebagai judul bagian akhir (IV) Yoga-Sūtras, yakni Kaivalya Pāda. Menurut Sri Aurobindo, Rāja-yoga bertujuan untuk mencapai pembebasan dan penyempurnaan diri mental, yakni pengendalian seluruh perangkat pencerapan, emosi, pikiran, dan kesadaran. ${ }^{15}$

Jñāna-yoga adalah jalan spiritual sistem Vedānta yang bertujuan untuk mencapai realisasi-Diri (Self-realisation) melalui kearifan (wisdom). Metodenya adalah melalui teknik "refleksi intelektual" (vicāra) dan "diskriminasi yang benar" (viveka). ${ }^{16}$

Hatha-yoga juga bertujuan untuk mentransendensikan ego dan merealisasikan Diri (Self) melalui teknik āsanas, prānāyāma, mantra, dan mudrā. Hatha-yoga memusatkan perhatian pada tubuh (body), agar dapat bertahan terhadap realisasi transendental. Karenanya, pelajar Hathayoga menempa tubuh dan menguatkan-nya. ${ }^{17}$ Dengan menyempurnakan tubuh fisik dan prāna, praktisi Hatha-yoga mencapai tujuan mereka, yakni penyatuan dengan Realitas absolut (Brahman). ${ }^{18}$

Bhakti-yoga mengajarkan bahwa tujuan yoga adalah untuk mencapai realisasi Diri melalui "devosi" (bhakti) kepada Tuhan. Jika Rāja-yoga dan Jñ̄na-yoga mencapai realisasi Diri melalui transedensi dan transformasi

12 Sri Aurobindo, Essays Divine and Human, p. 345.

13 Sri Aurobindo, Essays Divine and Human, pp. 346-347.

14 Ernest Wood, Seven Schools of Yoga (A Quest Book) (Wheaton, Il.: The Theosophical Publishing House, 1973), p. 17.

15 Sri Aurobindo, The Synthesis of Yoga (Silver Lake: Lotus Light Publications, nd.), pp. 30-31.

16 Georg Feuerstein, The Yoga Tradition: Its History, Literature, Philosophy and Practice (New Delhi: Bhavana Books \& Prints, 2002), p. 40.

17 Georg Feuerstein, The Yoga Tradition, pp. 38-39.

18 K.R.S. Iyengar, Sri Aurobindo: A Biography and a History (Pondicherry: Sri Aurobindo International Centre of Education, 2006), p. 553. 
pikiran, maka Bhakti-yoga mencapainya melalui pemurnian serta pengarahan kekuatan emosional (hati) pada yang Ilahi, agar dapat menjadi salurannya. ${ }^{19}$

Menurut sistem Karma-yoga, tujuan yoga adalah tindakan yang bebas dari pamrih (nishkama karma). Georg Feuerstein berpendapat bahwa tujuan Karma-yoga adalah kebebasan dalam tindakan (freedom in action), yakni tindakan yang melampaui motivasi ego. ${ }^{20}$

Dalam Bhagavad-Gìtā, Karma-yoga dijelaskan sebagai "tindakan tanpa pamrih" (yoga is skill in action). ${ }^{21}$ Tujuan langsung Karma-yoga adalah mencegah terjadinya penumpukan karma buruk serta membalikkan karma yang ada. ${ }^{22}$

Menurut Ernest Wood, tujuan "yoga kehendak" (Rāja-yoga) Pātañjali adalah melemahkan kelima kleśas, ${ }^{23}$ yakni kebodohan, atau kegelapan batin (avidyā), ke"aku"an, atau egoisme (asmitā), kemelekatan (rāga), kebencian (dvesha) dan kehendak untuk hidup (abhiniveśa). ${ }^{24}$

Dalam Yoga-Sūtras bagian Sādhana Pāda (II, 2), dikatakan, “Kriyā-yoga ${ }^{25}$ dilatih untuk melemahkan atau mengurangi kleśas dan menghasilkan kondisi samāahi." Filsafat kleśas ini memang merupakan fondasi sistem yoga yang dirumuskan oleh Pātañjali. Filsafat ini dapat memberikan jawaban yang memuaskan atas pertanyaan "Mengapa kita harus berlatih yoga?" 26

19 Georg Feuerstein, The Yoga Tradition, p. 48.

20 Georg Feuerstein, The Yoga Tradition, p. 63.

21 S. Radhakrishnan, The Bhagavadgita (London: George Allen \& Unwin Ltd., 1953), pp. 120-121.

22 Georg Feuerstein, The Yoga Tradition, p. 65.

23 Kleśa (Sanskerta) adalah penderitaan atau apa yang menyebabkan terjadinya penderitaan, kesusahan atau kesakitan. Filsafat kleśas menganalisis penyebab mendasar dari penderitaan serta kesusahan manusia, agar penyebabnya dapat dikurangi atau dihilangkan. I. K. Taimni, The Science of Yoga, pp. 135-136.

24 Ernest Wood, Seven Schools of Yoga, p. 19.

25 Menurut Pātañjali, Kriyā-yoga adalah ketiga langkah persiapan awal dalam yoga, yakni askese, studi dan penyerahan diri (tapas, svādhyāya dan Iśvara-pranidhāna) Lihat Sri Swami Satchidananda, The Yoga-Sütras of Pātañjali, p. 241. I.K. Taimni menjelaskan bahwa ketiga disiplin Kriyā-yoga mengembangkan ketiga aspek kodrat manusia. Tapas terkait dengan kehendak, Svādhyāya terkait dengan intelek, dan İśvara-pranidhāna terkait dengan emosi atau devosi. Bdk. Yoga-Sütras (Vol. II, p. 32). Kriyāa-yoga ini bersifat praktis dan sebagai persiapan awal untuk mencapai pertumbuhan individualitas yang seimbang. I. K. Taimni, The Science of Yoga: The Yoga-Sütras of Pātañjali in Sanskrit with Transliteration in Roman, Translation and Commentary in English (Adyar, Madras: The Theosophical Publishing House, 1986), pp. 128-129.

26 I. K. Taimni, The Science of Yoga, pp. 129-131. 


\section{RĀJA-YOGA DAN HATHA-YOGA}

Secara historis, sistem yoga yang paling penting adalah sistem Räjayoga klasik Pātañjali. Selain itu juga terdapat berbagai sistem yoga yang tidak sistematis, yang seringkali terkait dengan kepercayaan serta praktik populer. Menurut Feuerstein, dalam Hinduisme terdapat enam macam yoga utama, yaitu: Rāja-yoga, Jñanna-yoga, Hatha-yoga, Bhakti-yoga, Karmayoga, dan Mantra-yoga. Kemudian dalam perkembangannya, muncul dua bentuk yoga lain, yaitu Laya-yoga dan Kundhalini-yoga. Kedua yoga terakhir ini terkait erat dengan Hatha-yoga dan dapat digolongkan dalam Tantra-yoga. ${ }^{27}$

Dalam Yogatattva-Upanishad dan Varäha-Upanishad, hanya disebutkan empat jenis yoga: Mantra-yoga, Laya-yoga, Hatha-yoga dan Rājayoga. Semua yoga ini memasukkan teknik latihan, seperti: postur tubuh (āsanas), pengendalian napas (prānāyāma), meditasi (dhyāna) dan ekstasis (samädhi). Mantra-yoga adalah sistem yoga yang mencapai kesempurnaan melalui pengucapan mantra (japa).$^{28}$ Laya-yoga adalah suatu bentuk Hathayoga lebih tinggi untuk mencapai kesempurnaan melalui penyerapan diri ke dalam Diri transendental. Dalam Rāja-yoga dan Jñāna-yoga, proses "diskriminasi" (viveka) melalui teknik vicāra yang melibatkan intelek menjadi penting. Dalam Mantra-yoga, penyembahan dan devosi menjadi unsur paling penting; sedangkan Hatha-yoga lebih menekankan metode fisik, seperti teknik āsanas dan prānāyāma, namun Jũāna-yoga mencapai "pengetahuan" (jñāna) melalui usaha mental, tanpa harus membangkitkan energi kundhalini.$^{29}$ Semua yoga pada dasarnya menggunakan "delapan ruas" yoga (Ashtānga-yoga) sebagai prasyarat utama. ${ }^{30}$

Menurut Wood, yoga dapat dibagi menjadi tujuh aliran, yakni Rājayoga (Pātañjali), Karma dan Buddhi-yoga (Bhagawad-Gītā), Jñāna-yoga (Śankarācārya), Hatha-yoga, Laya-yoga, Bhakti-yoga dan Mantra-yoga. Ketiga yoga pertama dapat dikelompokkan dalam Rāja-yoga, sedangkan keempat yoga terakhir termasuk dalam Hatha-yoga. ${ }^{31}$

Ada perbedaan besar antara sistem Rāja-yoga dan Hatha-yoga. Yang pertama melatih pengembangan kesadaran atau pengendalian

27 Georg Feuerstein, The Yoga Tradition, p. 36.

28 Japa (Sanskerta) artinya pengulangan (repetition); pengulangan nama Tuhan atau sebuah mantra. Japa ini dipraktikkan secara lisan, berbisik atau secara mental. Lihat John Grimes, A Concise Dictionary of Indian Philosophy (Albany: State University New York Press, 1996), p. 145.

29 Kundhalinī (Sanskerta) artinya ular, daya hidup; energi primordial (shakti), energi kosmis yang tinggal di cakra dasar (müladhara) setiap manusia. Lihat John Grimes, A Concise Dictionary of Indian Philosophy, p. 171.

30 K. Narayanasvami Aiyar (Trans.), Thirty Minor Upanishads (Madras: np, 1914), p. 238; juga A. Avalon, The Serpent Power (New York: Dover Publicatios, Inc., 1974), p. 186.

31 Ernest Wood, Seven Schools of Yoga, p. 12. 
pikiran, sedangkan yang kedua adalah sebuah metode yang bertujuan memurnikan serta mengembangkan tubuh sebagai sarana, sehingga kekuatan fisik-psikis dapat menjadi aktif. Yang pertama disebut Rājayoga, karena manusia menjadi raja atau penguasa atas kemampuannya sendiri; sedangkan yang kedua disebut Hatha-yoga, karena menekankan metode khusus dalam melatih masuk-keluarnya napas (ha dan tha), untuk mempengaruhi tubuh agar nantinya dapat mempengaruhi sang Diri (Self). ${ }^{32}$

Tradisi yoga tidak pernah berhenti tumbuh, karena ia beradaptasi dengan kondisi sosial-budaya yang baru. Ini terbukti dengan munculnya sistem Yoga Integral Sri Aurobindo pada abad ke-20. Yoga integral merupakan sebuah pendekatan modern yang unik, berdasarkan yoga tradisional, tetapi melampauinya melalui sebuah sintesis yang bersifat evolutif. Jadi, yoga bukan merupakan sebuah keseluruhan yang homogen. Setiap aliran dan Guru memiliki teknik serta metode latihan yang berbeda; akibatnya, banyak aliran yoga yang orientasi serta kerangka teoretisnya saling bertentangan satu sama lain. Seringkali juga terdapat tujuan yang berbeda, walaupun semuanya merupakan sarana untuk mencapai pembebasan (liberation). ${ }^{33}$

Sebagai contoh, cita-cita Räja-yoga adalah mengembalikan identitas Diri transendental (Purusha), yang secara abadi terpisah dari basis material, Alam (Prakriti). Sedangkan idealnya pelajar Hatha-yoga bertujuan menciptakan sebuah tubuh abadi untuk diri sendiri yang memungkinkan penguasaan menyeluruh terhadap alam. Aliran tertentu mengembangkan kekuatan paranormal, sedangkan aliran lain menganggapnya sebagai hambatan dalam proses yoga, sehingga meminta pelajar yoga untuk menghindarkannya sama sekali. Walaupun terdapat berbagai tradisi yoga yang berbeda, namun semua aliran setuju pada perlunya transendensi diri untuk mengatasi personalitas biasa. Jadi, yoga adalah sebuah teknik transendensi (ekstasis). Perbedaan berbagai aliran yoga terletak pada cara bagaimana transendensi ini dicapai dan dikonseptuali-sasikan. ${ }^{34}$

Memang penting bahwa kita harus tetap sensitif terhadap distingsi antara tujuan magis dan karya transformasi spiritual serta bahwa tujuan yoga adalah untuk melampaui pencapaian pengalaman serta kemampuan paranormal, karena tujuan spiritual yang otentik adalah realisasi-Diri (Self-realisation) berdasarkan pada transendensi diri.

Menurut Sri Aurobindo, Hatha-yoga bersifat psiko-fisis, sedangkan

32 Ernest Wood, Seven Schools of Yoga, p. 13.

33 Georg Feuerstein, The Yoga Tradition, p. 36.

34 Georg Feuerstein, The Yoga Tradition, p. 36. 
Rāja-yoga bersifat mental, psikis dan spiritual; namun semua kekuatan adalah tunggal, yakni kekuatan sang jiwa. ${ }^{35}$ Dalam Hatha-yoga, tubuh fisik menjadi pelaku utama untuk transformasi dan prinsip tindakan didasarkan pada hubungan antara tubuh dan jiwa. Tubuh adalah sebuah jembatan mistik antara yang fisik dan yang spiritual. Para pelajar Hathayoga mencapai pengedalian energi vital tubuh melalui latihan āsanas dan prānāyāma. ${ }^{36}$

Dalam Rāja-yoga, pikiran (manas) merupakan sebuah panggung tindakan dan medan kemenangan. Melalui teknik pengendalian gerak pikiran (yoga-citta-vritti-niroda), praktisi Räja-yoga mencapai penguasaan kesadaran secara menyeluruh. Teknik āsanas dan prānāyāma masih dipakai jika diperlukan. Tujuan akhir Rāja-yoga adalah 'trance' (samādhi). Kondisi ini tercapai jika pikiran murni yang tenang larut dalam kesadaran Suprakosmis tertinggi. Prosesnya melalui tiga tahapan: penarikan inderaindera fisik (vairāgya), konsentrasi (dhāranā) dan samādhi. Inilah jalan serta tujuan akhir Rāja-yoga. ${ }^{37}$

\section{RĀJA-YOGA: YOGA KERAJAAN}

Secara etimologis, kata Räja-yoga berarti yoga kerajaan (royal yoga). Istilah Rāja-yoga baru dipakai di India pada abad ke-16, dan secara khusus merujuk pada sistem yoga yang disusun oleh Pātañjali pada abad ke-2 s.M., dan kemudian dikenal sebagai Yoga-Sūtras. Sistem Rājayoga menggunakan metode "delapan ruas yoga" (Ashtānga-yoga) untuk mencapai kondisi samädhi. Metode inilah yang membedakan Rāja-yoga dari sistem Hatha-yoga yang lebih menekankan olah fisik. ${ }^{38}$

Penggunaan kata Rāja-yoga menunjukkan bahwa sistem yoga ini lebih unggul dibandingkan dengan sistem Hatha-yoga. Mengapa? Karena Hatha-yoga ditujukan pada mereka yang memang tidak mampu untuk melakukan latihan meditasi dan penyangkalan diri (renunciation), sedangkan Räja-yoga harus dimengerti sebagai yoga yang dirancang untuk para ksatria yang mau melatih dan mengendalikan pikiran mereka. Namun semua kualifikasi ini tidak semuanya benar dan sesuai dengan fakta, karena sistem Hatha-yoga juga memiliki latihan meditasi intens yang dapat mencapai ideal yang dicita-citakan oleh Rāja-yoga. ${ }^{39}$

35 Sri Aurobindo, The Synthesis of Yoga, p. 584.

36 Sri Aurobindo, The Synthesis of Yoga, p. 553.

37 K.R.S. Iyengar, Sri Aurobindo: A Biography and a History, p. 554.

38 Georg Feuerstein, The Yoga Tradition, p. 37.

39 Georg Feuerstein, The Yoga Tradition, p. 37. 
Rāja-yoga disebut demikian karena memang yoga ini dipraktikkan oleh para raja, terutama raja Bhoja (abad ke-10). Raja Bhoja bahkan menulis komentar atas Yoga-Sūtras Pātañjali. Komentar Bhoja ini memberikan penjelasan yang lebih esoteris. Sebagai contoh, kata rāja yang dapat diartikan sebagai merujuk pada Diri transendental atau penguasa (raja) dari pikiran dan tubuh. Dalam tradisi yoga, Diri (Self) digambarkan sebagai sesuatu yang "bercahaya" (rajate). Kata rajate diturunkan dari akar kata kerja yang sama, yakni rāja. ${ }^{40}$

Kata rāja dapat juga merujuk pada sang "penguasa" atau "Tuhan" (Iśvara) yang dikenali Pātañjali sebagai Diri transendental. ${ }^{41}$ Sebagian ahli berpendapat bahwa Pātañjali hidup di masa pra-Kristen dan Rājayoga merupakan sistem yoga yang paling berpengaruh dalam konteks Hinduisme. Rāja-yoga Pātañjali adalah sebuah jalan mulia menuju "meditasi" (dhyāna) dan "kontemplasi" (samādhi).

Menurut Swami Vivekananda, Rāja-yoga adalah sainsnya agama, rasionalitas dari semua bentuk pemujaan, upacara dan keajaiban..$^{42}$ Rajayoga mengajarkan bagaimana cara memfokuskan pikiran; menemukan ketenangan pikiran serta membuat kesimpulan kita sendiri. Pada akhirnya, pencarian meditatif ini akan membimbing kepada penemuan Realitas transendental melampaui pikiran dan imaji; melampaui pemujaan dan doa, serta melampaui ritual dan sihir. ${ }^{43}$

Rāja-yoga tidak mulai dengan tubuh fisik dan energi hidup (prāna), namun dengan pikiran manusia. Rāja-yoga juga tidak membuang āsanas dan prānāyāma, tetapi memisahkannya ke tahap berikutnya, yakni lebih mementingkan yama dan niyama, yang merupakan disiplin untuk menaklukkan nafsu serta keinginan rendah manusia; dan melalui peningkatan kemurnian diri serta ketenangan moral, untuk membantu konsentrasi kesadaran pada yang Absolut. ${ }^{44}$

Sistem Yoga ini bertujuan untuk mencapai pembebasan dan penyempurnaan diri mental, yakni pengendalian kehidupan emosional dan pencerapan, penguasaan seluruh perangkat pikiran serta kesadaran, bukan diri fisik. Räja-yoga memusatkan diri pada citta, ${ }^{45}$ yakni bahan

40 Georg Feuerstein, The Yoga Tradition, p. 37.

41 Georg Feuerstein, The Yoga Tradition, p. 38.

42 Swami Vivekananda, "Raja-yoga or Conquering the Internal Nature," p. 66, dikutip dalam G. Feuerstein, The Yoga Tradition, p. 38.

43 Swami Vivekananda, The Complete Works of Swami Vivekananda: Mayawati Memorial Edition, Part II (Almora, Himalayas: Advaita Ashrama, 1932), p. 131.

44 Rishabhchand, The Integral Yoga of Sri Aurobindo, pp. 21-22.

45 Citta (Sanskerta) diturunkan dari akar kata kerja cit (to perceive, observe, know), artinya pikiran, kesadaran (mind, thought, consciousness). Dalam Räja-yoga, citta berarti piki- 
kesadaran mental yang menimbulkan semua aktifitas. Seperti juga Hatha-yoga, pertama-tama Räja-yoga berusaha mencapai pemurnian serta penenangan diri. ${ }^{46}$

Apabila pikiran sudah diam, keinginan pun akan padam pada tahap tertentu dan egoisme agresif berkurang atau hilang sama sekali. Rāja-yoga adalah sebuah ilmu kuno dari budaya spiritual dan metode 'delapan ruas yoga' (Ashtānga-yoga) mendapat penghormatan serta kepercayaan dari para pelajar yoga. Tujuannya adalah menenangkan tubuh, memurnikan sistem syaraf serta mengendalikan energi hidup, agar tidak menghambat atau menganggu konsentrasi dan meditasi untuk masuk ke dalam kondisi samādhi. Jainisme serta Buddhisme pun banyak berhutang pada Räja-yoga dalam hal pemurnian pikiran untuk mencapai pembersihan dan penenangan kesadaran, sehingga dapat masuk dalam ketenangan meditasi yang utuh. ${ }^{47}$

\section{RINGKASAN ISI TEKS YOGA-SŪTRAS}

Dalam literatur yoga, teks Yoga-Sütras masih tetap menjadi otoritas paling penting di samping teks-teks lainnya, seperti Hatha-Yoga-Pradipika, Gherandha Samhitā, Laghu-Yoga-Vāsishtha, dan Yoga Upanishads. Seluruh teks Yoga-Sütras berisi seratus sembilan puluh enam ayat (sūtras) yang terbagi dalam empat bagian: Bagian I (Samādhi Pāda), Bagian II (Sädhana Pāda), Bagian III (Vibhūti Pāda), dan Bagian IV (Kaivalya Pāda).

Bagian pertama membahas tentang ciri-ciri umum serta teknik-teknik yoga. Bagian ini menjawab pertanyaan "Apa itu yoga?" Karena samādhi merupakan teknik yoga yang paling esensial, maka samädhi menduduki posisi utama dalam berbagai topik yoga. Karenanya, bagian ini disebut Samādhi Pāda.

Bagian awal Sādhana Pāda menjelaskan filsafat kleśas dan menjawab pertanyaan "Mengapa kita harus berlatih yoga?" Filsafat kleśas ${ }^{48}$

ran, dan dalam Advaita-Vedānta kata citta merujuk pada kesadaran bawah sadar (subconscious); dalam sistem Yoga, "intelek" (buddhi), ego (ahamkāra) dan indera-indera (indriyas) seringkali disebut citta. Lihat John Grimes, A Concise Dictionary of Indian Philosophy, p. 106.

46 Sri Aurobindo, The Synthesis of Yoga, pp. 30-31; juga dikutip dalam Rishabhchand, The Integral Yoga of Sri Aurobindo, pp. 21-22.

47 Rishabhchand, The Integral Yoga of Sri Aurobindo, p. 22.

48 Kleśas (Sanskerta) artinya hambatan, gangguan. Lihat S. Swami Satchidananda (Transl.), The Yoga-Sūtras of Pātañjali, p. 241. Menurut Buddhisme kilesa (Pāli) artinya kotoran batin. Ada sepuluh kotoran batin: ketamakan, kebencian, kebodohan batin, kesombongan, kekeliruan, keraguan, kemalasan, kegelisahan, tidak tahu malu, dan tidak takut. Lihat Panjika \& N. Perawira, Kamus Baru Buddha Dhamma (Jakarta: Tri Sattva Budhist Centre, 1993), hlm. 109. 
memberikan sebuah analisis detail mengenai kondisi manusia serta penderitaan yang inheren dalam kondisi ini. Filsafat kleśas harus dimengerti secara menyeluruh, jika orang ingin masuk ke dalam jalan yoga. Bagian kedua Sādhana Pāda membahas teknik "eksternal" yoga (bahiranga), yakni: yama, niyama, āsanas, prānāyāma, dan pratyāhāra. Latihan ini dimaksudkan sebagai persiapan untuk menuju tahap samādhi dan membuat pelajar yoga siap secara fisik, emosional, mental, dan moral untuk latihan yoga lebih tinggi, yang disebut sädhana.

Bagian pertama Vibhūti Pāda membahas ketiga teknik "internal" (antaranga), yakni konsentrasi (dhāranā), meditasi (dhyāna) dan kontemplasi (samādhi). Ketiga teknik latihan ini seringkali juga dikenal sebagai samyama. Melalui latihan samyama ini para yogi mencapai kondisi samādhi, dan memperoleh kemampuan-kemampuan luar biasa (siddhis). Pada bagian kedua, semua pencapaian tersebut dibahas secara detail dan karenanya bagian ini disebut Vibhūti Päda.

Bagian keempat atau akhir (Kaivalya Pāda) menjelaskan semua masalah pokok filosofis yang terlibat dalam studi dan latihan yoga. Bagian ini membahas kodrat pikiran, persepsi mental, hasrat, serta akibat-akibat yang mengikat atau menimbulkan kemelekatan. Pembebasan (liberation) serta akibat-akibatnya juga dibahas secara singkat dan sistematis, sehingga para pelajar yoga mendapatkan latarbelakang pengetahuan teoretis yang memadai. ${ }^{49}$

\section{DELAPAN LANGKAH TRANSENDENSI DIRI (Ashtānga-yoga)}

Pātañjali menyusun "delapan ruas yoga" (Ashtānga-yoga) sebagai sebuah metode spiritualitas praktis dalam Yoga-Sūtras (2.29):50

1. Disiplin Moral (Yama);

2. Disiplin Diri (Niyama);

3. Postur Tubuh (Āsana);

4. Pengendalian Napas (Prānāyāma);

5. Pengendalian Indera (Pratyāhāra);

6. Konsentrasi (Dhāranā);

7. Meditasi (Dhyāna);

8. Penyatuan (Samādhi). ${ }^{51}$

49 I. K. Taimni, The Science of Yoga, pp. viii-ix.

50 John Grimes, A Concise Dictionary of Indian Philosophy, p. 64; Jayadeva Yogendra \& Clement J. Vaz (Eds.), Yoga Today, tanpa halaman, sesudah daftar isi.

51 Georg Feuerstein, The Yoga Tradition, p. 324; juga Sri Swami Satchidananda (Transl.), 
Kedelapan ruas yoga (Ashtānga-yoga) Pātañjali seringkali digambarkan sebagai langkah atau tangga yang membimbing manusia dari kehidupan biasa menuju ke realisasi Diri dan melampaui personalitas ego.

Kedelapan aspek yoga tersebut dapat dilihat dari dua perspektif. Pertama, sebagai unifikasi kesadaran yang tumbuh. Kedua, sebagai pemurnian diri yang progresif. Kedua sudut pandang ini tercermin jelas dalam Yoga-Sütras. Sekarang kita akan membahas "delapan ruas" Rājayoga Pātañjali tersebut.

\subsection{Disiplin Moral (Yama)}

Definisi yama dijelaskan dalam Yoga-Sütras (2.30) sebagai berikut: "Yama terdiri atas tanpa kekerasan, kebenaran, tidak mencuri, selibat, dan ketidaktamakan." ${ }^{52}$ Seperti juga semua spiritualitas otentik, fondasi yoga dibangun atas sebuah etika universal. Karenanya, ruas pertama yoga Pātañjali bukanlah postur tubuh atau meditasi, melainkan disiplin moral (yama). Latihan disiplin ini meliputi lima kewajiban moral: tidak menyakiti (ahimsā), kebenaran (satya), tidak mencuri (asteya), selibat (brahmacarya), dan ketidaktamakan (aparigraha). ${ }^{53}$ Sikap moral ini dimaksudkan untuk mengendalikan kehidupan insting dan merupakan sebuah prasyarat penting untuk mencapai latihan yoga yang berhasil. Kelima disiplin moral ini dijelaskan dalam Yoga-Sūtras (2.31): "Sumpah agung ini tidak dibatasi oleh golongan, waktu, tempat dan keadaan." 54

Pertama, tanpa kekerasan (Ahimsā). Dari semua kewajiban moral, ‘tidak meyakiti' adalah yang paling utama. Kata ahimsā seringkali diterjemahkan sebagai "tidak membunuh," namun ini tidak tidak memberikan arti yang penuh dari kata ahimsā ${ }^{55}$ Dalam Yoga-Sūtras (2. 35), ahimsā didefinisikan sebagai berikut: "Jika ahimsā sudah dilaksanakan secara mantap, maka semua kebencian akan berhenti." 56

Sebenarnya, ahimsā adalah "tanpa kekerasan" dalam pikiran serta tindakan. Ia menjadi dasar dari disiplin yang lain. Keinginan untuk tidak menyakiti yang lain bersumber dari dorongan ke arah unifikasi dan transendensi sang ego. ${ }^{57}$

Kedua, kebenaran (satya). Kebenaran (satya) seringkali ditinggikan dalam literatur etika dan yog $a_{1}^{58}$ karena bagi orang yang sudah menjalankan

The Yoga-Sūtras of Pātañjali, pp. 124 -125.

52 Sri Swami Satchidananda (Transl.), The Yoga Sūtras of Pātañjali, p. 125.

53 Georg Feuerstein, The Yoga Tradition, p. 325.

54 Sri Swami Satchidananda (Transl.), The Yoga-Sūtras of Pātañjali, p. 126.

55 John Grimes, A Concise Dictionary of Indian Philosophy, p. 20.

56 Sri Swami Satchidananda (Transl.), The Yoga-Sütras of Pātañjali, p. 130.

57 Georg Feuerstein, The Yoga Tradition, p. 325.

58 Georg Feuerstein, The Yoga Tradition, p. 325; John Grimes, A Concise Dictionary of Indian Philosophy, pp. 290-291. 
kebenaran, kejujuran, semua tindakan serta akibatnya akan tunduk padanya. Dalam Yoga-Sütras (2. 36) dikatakan bahwa “Bagi orang yang sudah menjalankan kebenaran dan kejujuran, semua tindakan serta akibatnya ada di bawah kendali dirinya." 59

Ketiga, tidak mencuri (Asteya). Tidak mencuri (asteya) terkait erat dengan ahims $\bar{a}$, karena pemilikan benda berharga secara tidak benar, melanggar hak orang yang ia curi. ${ }^{60}$ Menurut Yoga-Sütras (2. 37), asteya dapat didefinisikan sebagai: "Jika asteya sudah ditanamkan, maka semua kekayaan akan datang." ${ }^{\prime \prime}$

Keempat, kesucian-kemurnian (Brahmacarya). Selibat (brahmacarya), yang secara harfiah berarti "tingkah laku Brahmana," merupakan hal penting yang inti dalam kebanyakan tradisi spiritual dunia, walaupun ditafsirkan secara berbeda. ${ }^{62}$ Dalam Yoga-Sütras (2. 38), Brahmacarya dijelaskan sebagai: "Dengan menjalankan brahmacarya, orang mendapatkan kekuatan." 63

Dalam sistem Yoga, selibat didefinisikan dalam istilah asketisme, yakni menahan diri dari aktivitas seksual, baik dalam perbuatan maupun dalam pikiran. Secara umum, rangsangan seksual dianggap menghambat dorongan ke arah pencerahan.

Kelima, ketidaktamakan (aparigraha). Ketidaktamakan (aparigraha) didefinisikan sebagai "tidak menerima hadiah," karena hadiah tersebut akan menimbulkan keterikatan serta rasa takut akan kehilangan. Jadi, para yogi dianjurkan untuk menumbuhkan kesederhanaan dengan sengaja. Terlalu banyak kepemilikan akan mengganggu pikiran. Penyangkalan diri (renunciation) merupakan sebuah aspek integral dari kehidupan seorang yogi. Yoga-Sütras (2.39) memberikan definisi aparigraha sebagai: "Jika aparigraha sudah tertanam, maka akan datang sebuah iluminasi menyeluruh tentang bagaimana dan mengapa seseorang dilahirkan." ${ }^{64}$

Jika dikuasai sepenuhnya, maka masing-masing dari kelima keutamaan dapat memberikan kekuatan paranormal (siddhi). Sebagai contoh, penguasaan ahimsa akan menciptakan aura kedamaian di sekitar diri sang yogi yang dapat menetralisir semua rasa permusuhan serta

59 Sri Swami Satchidananda (Transl.), The Yoga-Sūtras of Pātañjali, p. 131; Georg Feuerstein, The Yoga- Sütras of Pātañjali, p. 85.

60 Georg Feuerstein, The Yoga Tradition, p. 326; juga John Grimes, A Concise Dictionary of Indian Philosophy, p. 64.

61 Sri Swami Satchidananda (Transl.), The Yoga-Sūtras of Pātañjali, p. 133; Georg Feuerstein, The Yoga-Sūtras of Pātañjali, p. 85.

62 Georg Feuerstein, The Yoga Tradition, p. 326; juga John Grimes, A Concise Dictionary of Indian Philosophy, p. 95.

63 Sri Swami Satchidananda (Transl.), The Yoga-Sūtras of Pātañjali, p. 137.

64 Sri Swami Satchidananda (Transl.), The Yoga-Sūtras of Pätañjali, p. 141. 
penguasaan kebencian. ${ }^{65}$

Melalui kebenaran (satya) seorang praktisi yoga mendapatkan kekuatan dengan selalu mewujudkan kata-katanya. Penguasaan keutamaan tidak mencuri (asteya) mendatangkan segala macam harta tanpa usaha yang keras, sedangkan ketidaktamakan (aparigraha) merupakan kunci untuk memahami kelahiran mereka sekarang, masa depan dan sebelumnya. ${ }^{66}$ Alasannya adalah mungkin karena keterikatan pada tubuh dan pikiran merupakan suatu bentuk ketamakan - sedangkan ketidaktamakan mengimplikasikan sebuah ketidakterikatan terhadap benda yang material, termasuk tubuh - dan dapat mengu-rangi kelupaan ingatan akan masa lalu mengenai eksistensi sebelumnya. ${ }^{67}$

Akhirnya, ketika para yogi sudah memantapkan "kesucian" (śauca), mereka mendapatkan sebuah kekuatan besar. Semua teks yoga setuju bahwa tindakan selibat (brahmacari) tidak membuat seorang yogi menjadi lemah. Sebaliknya, tindakan selibat akan memperkuat tubuh fisik. Kelebihan energi dapat digunakan oleh para yogi untuk transformasi spiritual dari personalitas. Karena itu, tindakan selibat menduduki posisi penting dalam tradisi spiritual dunia. Dalam yoga klasik, tindakan selibat diartikan sebagai menarik diri dari aktivitas seksual, baik dalam tindakan, pikiran, maupun dalam kata-kata. ${ }^{68}$

\subsection{Disiplin Diri (NIYAMa)}

Ruas kedua Rāja-yoga Pātañjali, yakni disiplin diri (niyama), bertujuan untuk mengendalikan energi psiko-fisik yang ditimbulkan dari pengendalian diri kehidupan batin para yogi. Jika kelima aturan disiplin moral (yama) bertujuan mengatur latihan disiplin moral yang teratur sebagai unsur konstitutif keselarasan dengan manusia lain, maka kelima aturan disiplin diri (niyama) bertujuan menyelaraskan hubungan kelima disiplin diri dengan kehidupan secara menyeluruh dan dengan Realitas Transendental. ${ }^{69}$ Kelima latihan pengendalian diri (niyama) adalah kesucian, kemurnian (śauca), berpuas diri (samtosha), askese (tapas), studi teks spiritual (svādhyāya), dan berserah diri pada Tuhan (Iśvarapranidhāna). ${ }^{70}$

65 Georg Feuerstein, The Yoga Tradition, p. 325; Sri Swami Satchidananda (Transl.), The Yoga-Sūtras of Pātañjali p. 130.

66 Sri Swami Satchidananda (Transl.), The Yoga Sūtras of Pātañjali, p. 141.

67 Georg Feuerstein, The Yoga Tradition, p. 326; Sri Swami Satchidananda (Transl.), The Yoga-Sūtras of Pātañjali, p. 141.

68 Georg Feuerstein, The Yoga Tradition, p. 326; Sri Swami Satchidananda (Transl.), The Yoga-Sūtras of Pātañjali, p. 137.

69 Georg Feuerstein, The Yoga Tradition, p. 327.

70 Georg Feuerstein, The Yoga Tradition, p. 327; Sri Swami Satchidananda (Transl.), The Yoga-Sūtras of Pätañjali, p. 127. 
Dalam Yoga-Sütras (2. 32), dijelaskan dijelaskan bahwa "Niyama terdiri atas kemurnian diri, berpuas diri, askese, studi teks spiritual dan penyerahan diri pada Tuhan."71

Pertama, kemurnian diri (śauca) merupakan kata kunci dalam spiritualitas yoga; karenanya, tidaklah mengherankan bahwa kemurnian diri termasuk dalam daftar pertama dari kelima disiplin diri. ${ }^{72}$ Dalam Yoga-Sūtras (2. 40) dijelaskan: "Melalui pemurnian diri timbul kemuakan terhadap tubuh sendiri dan terhadap sentuhan dari tubuh yang lain." ${ }^{73}$

Dalam kemurnian diri terdiri, terdapat perbedaan antara kebersihan lahir dan kemurnian batin. Kebersihan lahir dicapai melalui sarana, seperti mandi atau diet yang benar, sedangkan kemurnian batin diperoleh melalui sarana seperti konsentrasi dan meditasi. Akhirnya, personalitas dalam aspek tertinggi (sattva-aspect) haruslah begitu murni, sehingga ia dapat mencerminkan cahaya Diri Transendental (Transcendental Self) tanpa bias apapun. Amritabindu-Upanishad (1) mengatakan: "Pikiran dibicarakan, terutama sebagai dua macam pikiran yang murni dan yang tidak murni. Pikiran yang tidak murni adalah pikiran yang memiliki keinginan, sedangkan pikiran murni adalah pikiran yang tanpa keinginan" (Amritabindu Upanishad, 1). ${ }^{74}$

Kedua, berpuas diri (samtosha), artinya tidak menginginkan lebih dari apa yang sudah dimiliki. Berpuas diri merupakan keutamaan yang bertentangan dengan mentalitas konsumerisme modern yang didorong oleh kebutuhan untuk selalu mendapatkan lebih demi mengisi kekosongan batin. Berpuas diri adalah ungkapan dari penyangkalan diri, yakni pengorbanan secara sukarela akan apa yang menurut takdir akan diambil dari kita pada saat kematian. Samtosha membuat para yogi mengalami keberhasilan atau kegagalan, susah atau senang dengan ketenangan hati. ${ }^{75}$ Dalam Yoga-Sütras (2. 42), samtosha dijelaskan sebagai: "Dengan berpuas diri, kegembiraan tertinggi dicapai." 76

Di sini kita harus mengerti perbedaan antara "berpuas diri" (contentment) dan "kepuasan diri" (satisfaction). Berpuas diri artinya menjadi diri kita seperti apa adanya, tanpa mencari kebahagiaan dari benda-benda di luar. Jika sesuatu datang, kita biarkan ia datang jika

71 Sri Swami Satchidananda (Transl.), The Yoga-Sūtras of Pātañjali, p. 127; Georg Feuerstein, The Yoga-Sütras of Pātañjali, pp. 81-82.

72 Georg Feuerstein, The Yoga Tradition, p. 327.

73 Sri Swami Satchidananda (Transl.), The Yoga-Sūtras of Pätañjali, p. 142.

74 S. Radhakrishnan, The Principal Upanishads (London: George Allen \& Unwin Ltd.; New York: Humanities Press Inc., 1969), p. 844; Swami Madhavananda (Transl.), Minor Upanishads (Calcutta: Advaita Ashrama, 1988), p. 18.

75 Georg Feuerstein, The Yoga Tradition, p. 327.

76 Sri Swami Satchidananda (Transl.), The Yoga-Sūtras of Pātañjali, p. 146. 
tidak, tidak masalah. Berpuas diri artinya bersikap apa adanya, yakni tidak menyukai dan juga tidak membenci. ${ }^{77}$

Ketiga, askese (tapas) merupakan unsur atau komponen ketiga dari niyama dan mencakup latihan, seperti: berdiri atau duduk diam dalam waktu lama; menahan kelaparan, kehausan serta panas dan dingin; berdiam diri serta berpuasa. ${ }^{78}$ Kata $_{\text {tapas }}{ }^{79}$ berarti berkilau, "panas" dan merujuk pada energi psikosomatis yang dihasilkan dari latihan asketisme yang seringkali dialami sebagai rasa panas. Para yogi menggunakan energi ini untuk memanaskan kawah energi tubuh dan pikiran mereka, sampai menghasilkan kesadaran yang lebih luhur. Dalam Yoga-Sütras (2. 43) tapas dijelaskan oleh Pātañjali: "Melalui askese, ketidakmurnian tubuh serta indera-indera dihancurkan dan kesaktian dicapai."

Askese tidak boleh dikacaukan dengan penyiksaan diri. Dalam Bhagawad-Gìtā (17.14-19) dibedakan tiga macam asketisme, tergantung pada kecenderungan dari ketiga kualitas alam (gunas): Sattwika, Rajasika, dan Tamasika.

Ketiga macam pertapaan yang dilakukan dengan kepercayaan yang teguh oleh mereka yang pikirannya kuat untuk tidak menghendaki buahnya, dikatakan Sattwika, baik (Gītā. 17.17). ${ }^{80}$

Pertapaan yang dilakukan dengan tujuan untuk mendapatkan kehormatan, dan hanya sebagai pameran belaka, dikatakan Rajasika, dan adalah goyah dan tidak panjang umurnya (Gìtā. 17.18). ${ }^{81}$

Pertapaan yang dilakukan dengan kebodohan, keras kepala dengan jalan penyiksaan diri dan untuk menyakiti hati orang lain adalah Tamasika, bodoh (Gītā. 17.19) ${ }^{82}$

Keempat, studi teks spiritual (Svādhyāya). Studi teks spiritual merupakan komponen keempat dari niyama dan merupakan latihan yoga yang penting. Kata svādhyāya dibangun dari svā artinya "sendiri" dan adhyāya, artinya "masuk ke dalam." 83 Kata studi merujuk pada pencarian makna tersembunyi dari teks kitab suci. Tujuan svädhyāya bukanlah sebuah pembelajaran intelektual, melainkan penyerapan kedalam kearifan kuno. Svādhyāya merupakan sebuah renungan meditatif mengenai kebenaran

77 Sri Swami satchidananda (Transl.), The Yoga-Sütras of Pātañjali, p. 146.

78 Georg Feuerstein, The Yoga Tradition, p. 327.

79 John Grimes, A Concise Dictionary of Indian Philosophy, p. 315.

80 Ide Bg. Mantra (penerj.), Bhagawad-Gìtā, p. 241.

81 Ide Bg. Mantra (penerj.), Bhagawad-Gìtā (Denpasar: Parisada Hindu Dharma Pusat, 1970), p. 241.

82 Ide Bg. Mantra (penerj.), Bhagawad-Gìtā, p. 242.

83 Georg Feuerstein, The Yoga Tradition, p. 328; juga John Grimes, A Concise Dictionary of Indian Philosophy, p. 307. 
yang dibukakan oleh para Rishi dan arif bijaksana yang telah berjalan ke wilayah di mana pikiran tidak dapat mengikuti serta hanya hati yang dapat menerima. ${ }^{84}$ Dalam Yoga-Sūtras (2. 44) dikatakan bahwa "Dengan mempelajari teks-teks spiritual, akan terjadi penyatuan dengan dewa-dewi yang disembah." 85

Kelima, penyerahan diri kepada Tuhan (İśvara-pranidhāna). Unsur terakhir dari niyama adalah Iśvara-pranidhāna, artinya penyerahan diri secara menyeluruh kepada Tuhan (Iśvara). ${ }^{86}$ Dalam Yoga-Sütras (2. 45) dijelaskan bahwa "Melalui penyerahan diri secara menyeluruh, samādhi dicapai." 87

Ishvara adalah salah satu dari Diri transendental yang satu dan banyak (Purusha) ${ }^{88}$ Menurut definisi yang diberikan Pātañjali, status Ishvara yang luar biasa di antara banyak diri disebabkan oleh fakta bahwa Ia tidak akan pernah tunduk pada ilusi yang menghilangkan kemahatahuan serta kemahahadiran-Nya. Diri bebas yang lain, pernah sekali waktu mengalami kehilangan kemahatahuan dan kemahahadiran-Nya ketika mereka menganggap diri mereka sebagai sebuah personalitas egois partikular atau tubuh-pikiran terbatas. Secara inheren, semua diri adalah bebas, namun hanya Ishvara yang selalu sadar akan kebenaran ini. ${ }^{89}$

Ishvara di sini tidak sama dengan Pencipta seperti Tuhannya orang Yahudi dan orang Kristen, juga bukan sejenis 'keabsolutan universal' yang diajarkan dalam Upanishads atau teks Buddhisme Mahāyāna. ${ }^{90}$ Akibatnya, sebagian orang melihat Ishvara sebagai "penyusup" ke dalam sistem yoga klasik.

84 Georg Feuerstein, The Yoga Tradition, p. 328.

85 Sri Swami Satchidananda (Transl.), The Yoga-Sūtras of Pätañjali, p. 149.

86 Ishvara (Sanskerta) artinya jiwa kosmis tertinggi, “Tuhan.” Dalam Yoga Sūtras (I. 24), Ishvara dijelaskan sebagai suatu Purusha tertinggi yang tidak terkena oleh hambatan, tindakan, akibat dari tindakan, kesan batin dari keinginan apapun. Lihat Sri Swami Satchidananda (Transl.), The Yoga-Sütras of Pätañjali, p. 240.

87 Sri Swami Satchidananda (Transl.), The Yoga-Sūtras of Pātañjali, p. 149. Lihat juga Georg Feuerstein, The Yoga Tradition, p. 329; juga John Grimes, A Concise Dictionary of Indian Philosophy, p. 143.

88 Dalam Yoga-Sütras (I. 25), Purusha dijelaskan sebagai pengetahuan kosmis yang dikenal sebagai jiwa tertinggi (supreme soul). Lihat S. Swami Satchidananda (Transl.), The Yoga-Sūtras of Pātañjali, p. 40.

89 Georg Feuerstein, The Yoga Tradition, p. 329.

90 Mahāyāna (Sanskerta) artinya "kendaraan besar," juga dikenal sebagai Buddhisme Utara (Northern Buddhism) yang berkembang di India, Nepal, Tibet, Cina, Korea, Jepang adalah Buddhisme yang menekankan pencerahan universal, teknik visualisasi, metafisika, serta idealnya seorang Bodhisattva. Dua cabang utamanya adalah aliran idealistis Mādhyamika dan Yogācāra. Sedangkan aliran Hìnayāna/Theravāda (Southern School) yang berkembang di Selatan (Thailand, Kamboja, Sri Lanka) lebih menekankan pembacaan Paritta, kehidupan ideal seorang Arahat serta melihat Buddha sebagai manusia. Lihat John Grimes, A Concise Dictionary of Indian Philosophy, pp. 182-183. 
Ajaran Rāja-yoga Pātañjali bersifat teistis, ${ }^{91}$ sedangkan yoga praklasik bersifat panenteistis, ${ }^{92}$ dan yoga pasca klasik kembali menjadi panenteistis. Mengapa Pātañjali memberikan perhatian khusus pada doktrin Ishvara? Alasannya adalah sangat sederhana, karena Ishvara itu lebih dari sekedar konsep bagi Pātañjali dan para yogi di masa itu. Ide tentang Ishvara dan karunia sudah menjadi unsur yoga sejak masa paling awal, terutama sejak munculnya tradisi teistis dalam Bhagawad-Gìtā. Secara alami, pikiran religius cenderung untuk menyembah Realitas lebih luhur. Devosi kepada Tuhan (Ishvara) adalah pembukaan hati terhadap Wujud Transendental (Transcendental Being) yang bagi individu belum tercerahkan merupakan sebuah realitas dan daya objektif; namun setelah pencerahan Ishvara ditemukan serupa dengan Diri Transendental (Transcendental Self). Hal ini tidak dituliskan dalam Yoga-Sütras, namun terimplikasi dalam doktrin bahwa semua Diri Transendental, termasuk Ishvara, adalah abadi dan mahahadir; karenanya, walaupun mereka dibicarakan sebagai banyak, namun mereka harus serupa satu sama lainnya. ${ }^{93}$

\subsection{Postur Tubuh (Āsana)}

Secara harfiah, kata āsana berarti "dudukan." ${ }^{94}$ Kedua komponen dari "delapan ruas yoga" (Ashtānga yoga) Pātañjali, yakni yama dan niyama, berfungsi mengatur kehidupan sosial serta personal para praktisi yoga. Yama dan niyama adalah sebuah usaha untuk mengurangi terjadinya keinginan serta tindakan tidak baik, sehingga tidak menambah timbunan karma buruk yang baru dalam hidup ini.

Tujuan dari latihan yama dan niyama adalah untuk menghilangkan semua karma, yaitu semua penyebab subliminal yang tertanam di kedalaman jiwa (psyche). Untuk mewujudkan sebuah transformasi kesadaran, seorang yogi harus menciptakan kondisi lingkungan yang benar, baik di dalam maupun di luar diri. ${ }^{95}$ Yama-niyama merupakan

91 Teisme (Yunani) adalah ilmu yang mengajarkan tentang adanya Tuhan. Lihat J. S. Badudu, Kamus Kata-kata Serapan Asing dalam Bahasa Indonesia (Jakarta: Penerbit Buku Kompas, 2003), hlm. 344. Jenis agama, filsafat religius yang mengajarkan sebuah konsep bahwa Tuhan itu ada dan dapat dianggap sama dengan monoteisme. Dalam hubungannya dengan dunia, teisme berarti Tuhan bekerja di dalam dan melalui dunia. Dagobert D. Runes (Ed.), Dictionary of Philosophy (New Jersey: Littlefield, Adam \& Co., 1963), p. 316.

92 Panenteisme (Yunani) adalah pandangan yang menyatakan bahwa Tuhan ada di dalam semua, namun tidak identik dengan semua. Paham ini biasa dilawankan dengan Panteisme yang berarti bahwa Tuhan identik dengan semua hal; lihat Robert Audi (Ed.), The Cambridge Dictionary of Philosophy (New York: Cambridge University Press, 2006), p. 640.

93 Georg Feuerstein, The Yoga Tradition, p. 329.

94 Georg Feuerstein, The Yoga Tradition, p. 330; juga John Grimes, A Concise Dictionary of Indian Philosophy, p. 59.

95 Georg Feuerstein, The Yoga Tradition, p. 330. 
langkah awal untuk menciptakan kondisi lingkungan yang benar, sedangkan latihan berbagai postur tubuh (äsanas) adalah sebuah usaha untuk mengangkat tubuh ke tahap berikutnya. Secara esensial, āsanas adalah sebuah latihan untuk memurnikan dan mendiamkan tubuh fisik. Dalam Yoga-Sütras (2. 46), dikatakan: "Postur tubuh haruslah dalam kondisi stabil dan enak" (sthira sukham āsanam). ${ }^{96}$

Dengan melipat anggota tubuhnya, para yogi segera mencapai perubahan suasana dan ketenangan dalam batin. Ketenangan ini membantu untuk mempermudah proses konsentrasi pikiran. Sekelompok āsanas membentuk semacam "simbol" (mudras) $)^{97}$ yang memiliki makna simbolis. Bentuk mudras ini memiliki potensi kuat untuk mengubah kondisi sang yogi, karena mempengaruhi sistem kerja kelenjar endokrin tubuh. Melalui latihan yang teratur, praktisi yoga akan dapat menemukan perubahan yang terjadi sebagai akibat dari àsana tertentu. Menurut Pātañjali, latihan āsanas yang teratur dan benar akan menghilangkan sensitivitas terhadap dualisme ganda, seperti: panas dan dingin, terang dan gelap, hening dan ribut. ${ }^{98}$ Ada dua puluh tiga postur (āsanas) utama, yakni $^{99}$

$\bar{A}$ sanas dalam postur meditasi, misalnya:

Padmāsana: postur teratai (lotus);

Swastikāsana: postur swastika;

Vajrāsana: postur berlian;

Bhadrāsana: postur cakra; 100

Siddhāsana: postur Master; dan

Bhada Padmāsana: postur teratai dengan kedua tangan memegang ujung kaki.

Selain itu juga terdapat $\bar{A}$ sanas untuk kompresi perut, misalnya:

Mayūrāsana: postur burung merak; dan

Tolangulāsana: postur kura-kura terbalik.

$\bar{A}$ sanas untuk merentangkan tulang belakang (spine-stretch), seperti:

Bhujangāsana: postur ular;

Cakrāsana: postur cakra;

Dhanurvakrāsana: postur busur;

Yogāsana: postur yoga;

96 Sri Swami Satchidananda (Transl.), The Yoga-Sūtras of Pātañjali, p. 152.

97 John Grimes, A Concise Dictionary of Indian Philosophy, p. 194.

98 Georg Feuerstein, The Yoga Tradition, p. 330-331.

99 Jayadeva Yogendra \& Clement J. Vaz (Eds.), Yoga Today; lihat 23 gambar āsanas, di antara halaman 71-72.

100 Menurut P. J. Zoetmulder, Bhadrāsana dan Cakrāsana adalah identik. Lihat P.J. Zoetmulder, Old Javanese-English Dictionary. With the collaboration of S. O. Robson (SGravenhage-Martinus Nijhoff, 1982), pp. 73-74. 
Halāsana: postur bajak; $;^{101}$

Paśchimottanāsana: postur Barat-Utara; dan

Matsyendrāsana: postur Matsyendra.

Āsanas untuk melatih tangan dan kaki adalah:

Bakāsana: postur bangau;

Garudhāsana: postur garuda;

Dhanurāsana: postur busur;

Lolāsana: postur bangau bersila; dan

Talāsana: postur tiang (pilar).

Ada juga Āsanas dengan postur kepala di bawah, misalnya:

Sarvangāsana: postur lilin; dan

Padmāsana dalam potur Shirshāsana: postur kepala dalam postur teratai.

Yang terakhir adalah Āsana untuk relaksasi, yakni:

Savāsana: postur mayat.

Menurut Feuerstein, Dewa Shiva mengajarkan delapan puluh empat macam $\bar{A}$ sanas, namun postur-postur yang populer hanya berjumlah tiga puluh dua, yakni: ${ }^{102}$

Siddha-āsana: postur Master;

Padma-āsana: postur teratai;

Bhadra-āsana: postur cakra; ${ }^{103}$

Mukta-āsana: postur pembebasan;

Vajra-āsana: postur berlian;

Svastika-āsana: postur swastika;

Simha-āsana: postur singa;

Gomukha-āsana: postur muka sapi;

Vìra-āsana: postur pahlawan;

Dhanur-āsana: postur busur;

Mrita-āsana: postur mayat;

Gupta-āsana: postur rahasia;

Matsya-āsana: postur ikan;

Matsyendra-āsana: postur Matsyendra;

Goraksha-āsana: postur Goraksha;

Paśchimottāna-āsana: postur Barat-Utara; ${ }^{104}$

Utkata-āsana: postur luar biasa;

Samkata-āsana: postur bahaya;

Mayūra-āsana: postur burung merak;

101 Lihat P. J. Zoetmulder, Old Javanese-English Dictionary, p. 874.

102 Georg Feuerstein, The Yoga Tradition, p. 521.

103 Menurut P. J. Zoetmulder, Bhadrāsana adalah identik dengan Cakrāsana. Lihat P. J.

Zoetmulder, Old Javanese-English Dictionary, p. 73-74.

104 Lihat P. J. Zoetmulder, Old Javanese-English Dictionary, p. 1313. 
Kukkuta-āsana: postur ayam jantan;

Kürma-āsana: postur kura-kura;

Uttāna-kūrmaka-āsana: postur kura-kura menjulurkan dirinya;

Uttāna- mandhūka-āsana: postur kodok merentangkan diri;

Vriksha-āsana: postur pohon;

Mandhūka-āsana: postur kodok;

Garuda-āsana: postur burung garuda;

Vrisha-āsana: postur sapi;

Shalabha-āsana: postur belalang;

Makara-āsana: postur ikan hiu;

Ushtra-āsana: postur unta;

Bhujanga-āsana: postur ular; dan

Yoga-āsana: postur yoga.

\subsection{Pengendalian Napas (Prānāyāma)}

Kata prāna berarti daya hidup (life force), vitalitas. ${ }^{105}$ Kata prāna seringkali diterjemahkan sebagai napas (breath) dan hidup (life), padahal sebenarnya napas merupakan sebuah manifestasi luar dari prāna, yakni daya hidup yang menembus serta menopang semua kehidupan. ${ }^{106}$ Prānāyāma merupakan komponen keempat dari "delapan ruas yoga" Pātañjali. Seluruh petualangan yoga berpusat pada pengolahan prāna. ${ }^{107}$ Hal ini menunjukkan pentingnya prānāyāma dalam proses yoga.

Teknik prānāyāma adalah sebuah cara sistematis yang dikembangkan oleh para yogi untuk mempengaruhi medan bioenergi tubuh. Bahkan latihan disiplin moral (yama), pengendalian diri (niyama), pengendalian indera (pratyāhāra) dan konsentrasi mental (dhāranā), juga merupakan bentuk manipulasi daya prāna. Dalam budaya lain, ide tentang bioenergi prāna dikenal sebagai chi di Cina dan mana di dalam tradisi Polinesia. Para peneliti modern menyebutnya sebagai energi bioplasma. Para praktisi yoga mengetahui bahwa ada hubungan antara prāna, napas, emosi dan pikiran. ${ }^{108}$ Dalam Yoga-Sütras (2.49) dikatakan bahwa "Setelah menguasai äsanas, kita harus melatih keluar masuknya napas."109

Latihan pengaturan napas yang digabungkan dengan konsentrasi, prāna dapat dirangsang dan diarahkan. Tujuan yang hendak dicapai adalah bagian kepala atau persisnya, cakra di dalam otak. Jadi, prāna adalah sarana untuk meningkatkan kesadaran dalam tubuh dan otak. Jika napas atau prāna di dalam tubuh meningkat, maka perhatian akan

105 John Grimes, A Concise Dictionary of Indian Philosophy, p. 239.

106 Georg Feuerstein, The Yoga Tradition, p. 331.

107 Georg Feuerstein, The Yoga Tradition, p. 332.

108 Georg Feuerstein, The Yoga Tradition, p. 331.

109 Sri Swami Satchidananda (Transl.), The Yoga-Sūtras as of Pātañjali, p. 158. 
naik ke arah pengalaman lebih halus. Akhirnya energi prāna tersebut naik ke cakra mahkota di kepala. Bilamana energi prāna serta konsentrasi sudah dipusatkan pada cakra mahkota, maka kualitas kesadaran akan berubah secara radikal dan menghasilkan kondisi samādhi. ${ }^{110}$

\subsection{Pengendalian Indera (Pratyāhāra)}

Latihan āsanas dan prānāyāma menghasilkan sebuah desensitifikasi yang akan menghentikan rangsangan dari luar diri sang yogi. Kemudian secara berangsur sang yogi dapat hidup dalam lingkungan batin pikirannya sendiri. Jika kesadaran sudah dapat secara efektif membebaskan diri dari pengaruh lingkungan luar, maka kondisi tersebut disebut pratyāhāra. ${ }^{111}$ Dalam Mahābhārata (12. 194. 58) dikatakan tentang pratyāhära: "Sang Diri (Self) tidak dapat ditangkap dengan indera yang kacau, terpecah-belah dan terpencar serta sulit untuk dikendalikan bagi orang yang belum siap."112 Dalam Yoga-Sütras (2. 54), pengendalian indera (pratyāhāra) dijelaskan sebagai: "Jika indera-indera menarik diri dari objek (benda-benda) dan meniru seolah-olah memiliki kodrat materi pikiran, maka inilah yang disebut pratyāhāra."113

Dalam proses latihan pratyāhāra, sang yogi tidak boleh menangkap suara dengan telinga, merasakan sentuhan dengan kulit, melihat bentuk dengan mata dan mencicipi dengan lidah. Praktisi yoga juga harus menghindari segala macam bau dengan menarik inderanya ke dalam, berani menolak semua pengganggu, seperti kelima indera fisik. ${ }^{114}$

Walaupun para yogi melakukan pengendalian indera dan digambarkan sebagai "duduk diam seperti sebatang balok kayu," namun ini tidak berarti bahwa para yogi tersebut berada dalam kondisi tidak sadar dan tidak berdaya (coma). Sebaliknya, ketika kelima indera fisik satu per satu ditutup, pikiran akan menjadi sangat aktif. ${ }^{115}$

\subsection{Konsentrasi (DHĀRANĀ)}

Konsentrasi merupakan proses lanjutan dari pratyāhāra. Konsentrasi adalah komponen keenam dari Ashtānga-yoga Pātañjali. Konsentrasi dapat didefinisikan sebagai "memfokuskan perhatian pada satu tempat tertentu" (deśa). ${ }^{116}$ Tempat (locus) tersebut dapat merupakan bagian tertentu dari tubuh, seperti cakra atau objek eksternal, yang diinternalisasikan seperti imaji seorang dewa atau dewi. Istilah yang dipakai oleh Pātañjali untuk "konsentrasi" adalah dhäranā.

110 Georg Feuerstein, The Yoga Tradition, p. 331.

111 Georg Feuerstein, The Yoga Tradition, p. 332.

112 Mahābhārata, 12. 194. 58. Dikutip dalam Georg Feuerstein, The Yoga Tradition, p. 332.

113 Sri Swami Satchidananda (Transl.), The Yoga-Sūtras of Pātañjali, p. 165.

114 Georg Feuerstein, The Yoga Tradition, p. 332.

115 Georg Feuerstein, The Yoga Tradition, p. 332.

116 John Grimes, A Concise Dictionary of Indian Philosophy, p. 112. 
Dalam Yoga-Sütras (2. 53), dhāranā dijelaskan sebagai: "Dan pikiran sudah siap untuk konsentrasi" (Dhāranāsu ca yogyatā manasah). ${ }^{117}$ "Dhāranā adalah memfokuskan pikiran pada satu tempat, objek atau ide" (deśabandhaś cittasya dhāranā) (Yoga-Sütras 3. 1). ${ }^{118}$

Kata dhäranà berasal dari akar kata kerja dhri, artinya menahan. Apa yang ditahan adalah perhatian seseorang yang dipusatkan pada sebuah objek yang sudah diinternalisasikan. Proses yang melandasinya disebut ekāgrata, yang terdiri dari akar kata eka, artinya satu, dan agrata, artinya keterfokusan (pointedness). ${ }^{119}$

Keterfokusan adalah bentuk intensifikasi dari konsentrasi yang kita alami, misalnya pada saat bekerja secara intelektual;sedangkankonsentrasi biasa kebanyakan hanya merupakan sebuah kondisi yang keras serta gegabah dan diikuti oleh sejumlah besar ketegangan lokal. Jadi, dhāranā adalah seluruh pengalaman tubuh yang bebas dari ketegangan otot serta gangguan lainnya. Karenanya, melalui sebuah dimensi kedalaman psikis yang luar biasa, proses kreatif batin dapat dikembangkan.

Konsentrasi memang merupakan sebuah latihan yang sukar. Orang yang dapat mempertahankan konsentrasinya secara tetap, bahkan untuk jangka waktu yang singkat, adalah orang yang mahir dalam meditasi. ${ }^{120}$ Masalah konsentrasi ini dijelaskan dalam Yoga-Sūtras (1.30):

Terdapat sembilan hambatan yang mungkin muncul dalam usaha menenangkan pikiran, yakni penyakit, kebosanan, keraguan, kecerobohan, kemalasan, sensualitas, persepsi yang salah, kegagalan untuk mencapai dasar yang kuat dan menyimpang dari dasar. Gangguan tersebut adalah hambatan dalam meditasi. ${ }^{121}$

Hal ini seperti yang dijelaskan oleh Sankaracarya dalam Viveka Cudamani (325): "Bilamana kesadaran menyimpang, bahkan sedikit saja, dari tujuan dan terarah ke luar, maka kesadaran akan tenggelam, persis seperti sebuah bola yang jatuh melalui undakan tangga karena kecelakaan."122

117 Sri Swami Satchidananda (Transl.), The Yoga-Sūtras of Pātañjali, p. 164.

118 Sri Swami Satchidananda (Transl.), The Yoga-Sütras of Pātañjali, p. 171.

119 Georg Feuerstein, The Yoga Tradition, p. 332.

120 Georg Feuerstein, The Yoga Tradition, p. 333.

121 Sri Swami Satchidananda (Transl.), The Yoga-Sūtras of Pātañjali, (I. 30), p. 50.

122 Georg Feuerstein, Yoga tradition, p. 333; juga Mohini M. Chatterji (Transl.), VivekaCūdāmani or Crest Jewwel of Wisdom of Śrì Śamkarācārya (Adyar, Madras: The Theosophical Publishing House, 1983), p. 124. 


\subsection{Meditasi (DhYĀNa)}

Konsentrasi yang diperpanjang serta mendalam, secara alami akan membimbing seseorang ke kondisi yang disebut "meditasi" (dhyāna). Dalam meditasi, objek atau locus yang diinternalisasikan mengisi seluruh ruang kesadaran. Jika dalam "konsentrasi" mekanisme utama adalah "keterfokusan perhatian," dalam "meditasi" mekanisme yang mendasari proses ini adalah "kemengaliran yang tunggal" (ekatanata). ${ }^{123}$ Kondisi meditasi tidak menghilangkan kejernihan pikiran, malah sebaliknya ia memperkuat kesadaran, walaupun memang tidak ada atau terdapat sedikit sekali kesadaran akan lingkungan eksternal. Tujuan awal meditasi dalam yoga adalah untuk menahan, menekan serta menghentikan modifikasi aktivitas pikiran (citta-vritti-nirodha). ${ }^{124}$ Aktivitas mental tersebut meliputi lima kategori: ${ }^{125}$

Pramāna: pengetahuan yang diperoleh melalui persepsi, penyimpulan atau bukti yang dapat dipertanggungjawabkan, seperti teks kitab suci;

Viparyaya: kesalahpahaman, pengertian yang keliru;

Vikalpa: pengetahuan konseptual, imajinasi;

Nidra: tidur; dan

Smriti: ingatan.

Kedua aktivitas mental, yakni pramāna dan viparyaya, dapat dikalahkan melalui latihan pengendalian pancaindera (pratyāhära). Kecenderungan ke arah konseptualisasi berkurang bilamana proses latihan meditasi mulai mendalam. Tidur (nidra) yang disebabkan oleh unsur inertia (tamas) yang berlebihan, dapat diatasi dengan mempertahankan perhatian sadar melalui latihan konsentrasi dan meditasi. Ingatan (smriti) sebagai sumber munculnya fragmen pikiran atau gambaran mental yang sangat mengganggu para pemula praktisi yoga merupakan unsur terakhir yang harus dihilangkan. Ingatan (smriti) ini masih aktif dalam kondisi samādhi yang lebih rendah. Smriti menghasilkan ide dalam bentuk pandangan yang spontan (pratyaya) dan baru dapat ditransendensikan dalam realisasi puncak yang dikenal sebagai Asamprajñāta-samādhi. ${ }^{126}$

Dalam kondisi indentifikasi dengan Diri (Self), unsur pengaktif yang menyebabkan eksternalisasi kesadaran dicabut. ${ }^{127}$ Ingatan memiliki dua

123 Georg Feuerstein, The Yoga Tradition, p. 334.

124 Sri Swami Satchidananda (Transl.), The Yoga-Sütras of Pätañjali (1. 2), p. 3.

125 Georg Feuerstein, The Yoga Tradition, p. 334.

126 Asamprajūāta-samādhi (Sanskerta) adalah tahap samādhi dimana tidak ada lagi kesadaran objek apa pun dan pikiran berhenti berfungsi; sebuah penyatuan suprasadar. Lihat John Grimes, A Concise Dictionary of Indian Philosophy, p. 58.

127 Georg Feuerstein, The Yoga Tradition, p. 334. 
aspek, yakni aspek kasar dan aspek halus. Aspek kasar dari ingatan dapat dilumpuhkan melalui meditasi, sedangkan aspek halusnya da-pat dinetralkan melalui samādhi suprasadar. Ada tiga tahap proses "penghentian" (nirodha): $:^{128}$

1. Vritti-nirodha: penghentian kelima kategori aktivitas mental kasar dalam meditasi.

2. Pratyaya-nirodha: Penghentian ide (pratyaya) ${ }^{129}$ yang muncul dalam berbagai jenis samādhi sadar (Asamprajñäta-samādhi). Para yogi harus dapat mengatasi pikiran yang muncul secara spontan dalam kondisi Savitarka-samāpatti. ${ }^{130}$ Para yogi juga harus mampu melampaui rasa bahagia (ānanda) dalam kondisi Ānanda-samāpatti. ${ }^{131}$

3. Samskāra-nirodha: Penghentian unsur pengaktif batin dalam kondisi samādhi suprasadar (Asamprajñāta-samādhi). Dalam kondisi Asamprajñäta-samädhi, sang yogi melumpuhkan ingatan batin dengan potensi laten $(v \bar{a} s a n \bar{a} s)^{132}$ yang selalu menghasilkan aktivitas psikomental baru.

Masalah penghancuran samskāra ${ }^{133}$ dijelaskan dalam Yoga-Sūtras (1. 50): “Kesan (impresi) yang dihasilkan melalui samädhi akan menghapuskan semua kesan-kesan lainnya" (Taijah samskāro'nya samskāra pratibandhī). ${ }^{134}$

\subsection{Penyatuan (SAMĀDHi)}

Pada bagian konsentrasi dan meditasi, sudah dijelaskan bahwa konsentrasi (dhāranā) mengarah pada meditasi (dhyāna). Kemudian kita akan melihat bahwa "meditasi" (dhyāna) mengarah pada "penyatuan" (samādhi). Kondisi samādhi dapat tercapai jika semua modifikasi (vritti) dalam kesadaran bangun sudah dihentikan melalui latihan meditasi.

128 Georg Feuerstein, The Yoga Tradition, p. 335.

129 Pratyaya artinya ide, kondisi. John Grimes, A Concise Dictionary of Indian Philosophy, p. 248.

130 Samāpatti artinya pencapaian, kondisi manunggal dengan objek, sarana dan subjek kesadaran dalam meditasi. Savitarka berarti suatu jenis penyatuan (samädhi) dimana pikiran terkonsentrasi pada objek dan mengingat nama serta kualitasnya. Lihat John Grimes, Concise Dictionary of Indian Philosophy, pp. 272, 292.

131 Ānanda-samāpatti (Sanskerta), ānanda artinya kebahagiaan; sejenis samādhi dimana pikiran terpusat pada intelek (buddhi). Lihat John Grimes, Concise Dictionary of Indian Philosophy, p. 30.

132 Potensi laten, seperti kecenderungan, impresi, kondisi, keinginan yang melekat pada seorang individu; kata vāsanā adalah identik dengan samskāra. John Grimes, A Concise Dictionary of Indian Philosophy, p. 338.

133 Samskāra adalah kesan yang ditinggalkan dalam pikiran setelah terjadi sebuah pengalaman; dalam Buddhisme, samskāra adalah salah satu dari kelima unsur skandha; salah satu dari keduabelas mata rantai hukum penyebaban eksistensi (pratitya-samutpada). Lihat John Grimes, A Concise Dictionary of Indian Philosophy, p. 338.

134 Sri Swami Satchidananda (Transl.), The Yoga-Sütras of Pātañjali, p. 75. 
Karena itu, konsentrasi, meditasi dan penyatuan merupakan tiga fase dari satu proses yang berkesinambungan (samyama). Yoga-Sütras (3.3) memberikan definisi samādhi sebagai: "Samādhi adalah kondisi meditasi yang sama, di mana hanya ada objek saja, seolah tidak ada bentuknya." 135

Samādhi adalah suatu kondisi puncak yang dicapai melalui sebuah proses disiplin mental yang panjang dan sulit. ${ }^{136}$ Kondisi samādhi seringkali ditafsirkan secara pejoratif sebagai suatu kondisi trance yang tidak sadar atau sebuah kondisi schizophrenia yang disengaja. Ada dua hal yang jarang dimengerti orang awam tentang samädhi. Pertama adalah bahwa samādhi mencakup berbagai kondisi yang berbeda. Kedua, orang yang sudah mengalami kondisi penyatuan kesadaran ini dapat memastikan bahwa kejernihan mental merupakan salah satu ciri utamanya. Dalam Yoga-Sūtras (I. 17-18), Pātañjali menjelaskan tentang dua jenis samādhi, yakni, Samprajñāta-samādhi dan Asamprajūāta-samādhi. "Samprajñäta-samādhi diikuti oleh penalaran, refleksi, suka cita dan ke"Aku"-an yang murni." 137 "Setelah mantap dalam latihan menghentikan modifikasi pikiran secara menyeluruh, hanya kesan-kesan yang tinggal; inilah Asamprajūāta-samādhi."138

Kemudian, Pātañjali membagi Samprajñāta-samādhi dalam empat bentuk. Keempat bentuk samädhi ini terkait dengan unsur-unsur yang membentuk Prakriti, yakni materi kasar (mahäbhūtas), materi halus (tanmātras), materi pikiran (chitta), dan ego (ahamkāra). ${ }^{139}$

Keempat bentuk Samprajñāta-samādhi tersebut adalah, pertama, Savitarka-samādhi: jenis samādhi di mana pikiran terfokus pada suatu objek konkret tertentu. Kita harus ingat bahwa pada tahap ini, pikiran sudah terkendali dengan baik. Ketika pikiran yang sudah fokus tersebut mengkontemplasikan sebuah objek, maka ia akan masuk ke kedalaman objek tersebut dan mengerti setiap bagian terkecilpun. Pikiran yang terfokus menghasilkan kekuatan dan ketika pikiran tersebut terkonsentrasi pada sebuah objek, maka seluruh pengetahuan mengenai objek tersebut akan terbuka baginya. ${ }^{140}$

Kedua, savicāra-samādhi: Samādhi tahap berikutnya yang berkontemplasi pada unsur-unsur halus (tanmātras). Di sini tidak terdapat objek konkret yang dilihat. Kita berkontemplasi pada sesuatu yang

135 Sri Swami Satchidananda (Transl.), The Yoga-Sūtras of Pātañjali, p. 175; juga Georg Feuerstein, The Yoga-Sutra of Patanjali, p. 96-97.

136 Georg Feuerstein, The Yoga Tradition, p. 335.

137 Sri Swami Satchidananda (Transl.), The Yoga-Sūtras of Pātañjali, p. 31.

138 Sri Swami Satchidananda (Transl.), The Yoga-Sütras of Pātañjali, p. 35.

139 Sri Swami Satchidananda (Transl.), The Yoga-Sūtras of Pātañjali, p. 31.

140 Sri Swami Satchidananda (Transl.), The Yoga-Sūtras of Pātañjali, p. 32. 
lebih abstrak, seperti: warna putih, merah, cinta atau keindahan. Karena keabstrakannya, orang biasa tidak dapat mengerti apa itu "kemerahan" atau "cinta" tanpa bantuan sebuah objek konkret. Jika seseorang dapat berkontemplasi dan mengerti objek konkretnya juga, berarti pikiran sudah mampu mengerti benda-benda abstrak tanpa bantuan objek konkret; kemudian, orang tersebut juga akan mengatasi ruang dan waktu. ${ }^{141}$

Ketiga, sānanda-samādhi: kondisi samādhi yang lebih halus, di mana tidak ada lagi diskriminasi dan refleksi. Di sini intelek tidak digunakan, tetapi hanya berkontemplasi pada pikiran yang tenang itu sendiri. Dalam kondisi ini orang mencapai sebuah kebahagiaan mendalam. Inilah yang disebut sebagai Sānanda-samādhi (blissful samādhi). ${ }^{142}$

Keempat, sāsmita-samādhi. Dalam kondisi samādhi keempat ini, bahkan "kebahagiaan" pun sudah hilang, yang tertinggal hanyalah kesadaran akan individualitas. Objek kontemplasinya adalah ke-“aku”-an. Ini disebut Sāsmita-samādhi, artinya samādhi dengan ke-"aku"-an. Dalam Sāsmita-samādhi, kesan yang laten (samskāra) masih ada dalam pikiran, walaupun masih dalam bentuk benih. ${ }^{143}$

Dalam Samprajūāta-samādhi, ${ }^{144}$ benih yang laten masih dapat muncul ke permukaan pikiran sadar, jika ia mendapat kesempatan. Karenanya, keempat tahap Samprajñäta-samādhi harus dilewati dan masuk ke dalam Asamprajñäta-Samādhi, ${ }^{145}$ di mana bahkan perasaan ego pun tidak ada lagi dan benih kesan masa lampau dibuat tidak berdaya. Sang yogi tidak lagi diganggu oleh hal-hal duniawi, walaupun ia berada di dalam dunia. ${ }^{146}$

Berikut ini adalah skema tahap-tahap Samādhi menurut Feuerstein: ${ }^{147}$

141 Sri Swami Satchidananda (Transl.), The Yoga-Sūtras of Pātañjali, pp. 32-33.

142 Sri Swami Satchidananda (Transl.), The Yoga-Sūtras of Pātañjali, p. 33.

143 Sri Swami Satchidananda, The Yoga Sūtras of Pātañjali, p. 33.

144 Samprajñäta-samādhi (Sanskerta) adalah suatu tahap samädhi di mana seseorang masih sadar akan objek-objek, pikiran masih berfungsi dan berkonsentrasi pada sebuah objek pengetahuan. Lihat John Grimes, A Concise Dictionary of Indian Philosophy, p. 275.

145 Asamprajñäta-samādhi (Sanskerta) adalah sebuah tahap samādhi di mana tidak ada lagi kesadaran akan objek, sebuah penyatuan suprasadar. Pada tahap ini pikiran tidak lagi berfungsi. Lihat John Grimes, A Concise Dictionary of Indian Philosophy, p. 58.

146 Jivanmukta (Sanskerta) adalah orang yang sudah mencapai pembebasan (liberation) selagi masih hidup di dunia. Lihat John Grimes, A Concise Dictionary of Indian Philosophy, p.149; Sri Swami Satchidananda (Transl.), The Yoga Sūtras of Pātañjali, p. 35.

147 Georg Feuerstein, The Yoga Tradition, p. 335. 


\begin{tabular}{|c|}
\hline Kaivalya (Liberation) \\
\hline Dharma-megha-samadhi ("Cloud of Dharma" Ecstacy) \\
\hline Asamprajnata-samadhi (Supraconscious Ecstacy) \\
\hline Samprajnata-samadhi (Conscious Ecstacy) \\
\hline Nirasmita Samapatti(Ecstatic Coinciding beyond 'I-am-ness') \\
\hline Sasmita Samapatti(Ecstatic Coinciding with 'I-am-ness') \\
\hline Nirananda Samapatti (Ecstatic beyond Bliss) \\
\hline Sananda Samapatti (Ecstatic Coinciding with Bliss) \\
\hline Nirvicara Samapatti (Ecstatic Coinciding beyond Reflection) \\
\hline Sirvitarka Samapatti (Ecstatic Coinciding beyond Cogitation) \\
\hline Savitarka Samapatti (Ecstatic Coinciding with Cogitation) \\
\hline Dhyana (Meditation) \\
\hline Dharana (Concetration) \\
\hline Pratyahara (Sensory Inhibition) \\
\hline Vyutthama-Citta (Waking Consciousness)
\end{tabular}

Penyatuan (samādhi) selalu diikuti oleh suatu kondisi suprasadar. Jika kita menganggap bahwa berbagai kondisi samādhi itu tidak mungkin, maka kita tetap tidak dapat menyangkal bahwa kondisi samādhi tidak mengurangi kesadaran kita, malahan sebaliknya, membawa kita pada suatu kesadaran akan realitas yang lebih agung dan baik. Salah satu sumbangan pengetahuan yoga kepada dunia adalah adanya banyak bukti atas eksistensi sang wujud, yakni "Kesadaran Wujud Transendental" (Transcendental Being Consciousness) yang juga ditemukan dalam warisan budaya spiritual di Barat. Karena itu, kita harus berhati-hati dalam memberikan kritik serta penilaian terhadap kondisi, ide, serta latihan yoga, kecuali kita sendiri sudah memiliki pengalaman dan mengujinya secara netral. ${ }^{148}$ Mircea Eliade, seorang ahli di bidang sejarah agama dan yoga, mengingatkan:

Penyangkalan terhadap realitas pengalaman yoga, atau kritik atas sebagian aspek yoga tidak diperkenankan bagi orang yang tidak memiliki pengetahuan langsung tentang latihan yoga, karena kondisi yoga itu melampaui kondisi yang membatasi kita ketika kita mengeritiknya. ${ }^{149}$

148 Georg Feuerstein, The Yoga Tradition, p. 336.

149 Mircea Eliade, Yoga, Immortality and Freedom, translated from the French by Willard R. Trask. Bollingen Series LVI (nc: Routledge \& Kegan Paul, 1973), p. 39. 
Walaupun mungkin mendefinisikan apa itu samädhi, namun secara formal tidak ada penjelasan yang dapat memberikan gambaran tentang hakikat samādhi, karena tidak ada titik rujukan dalam kehidupan seharihari. Komponen penting yang tidak dapat disangkal dalam samädhi adalah pengalaman akan penyatuan menyeluruh antara subjek dan objek. ${ }^{150}$

\section{DAFTAR RUJUKAN}

Aiyar, Narayanasvami K. (Transl.). Thirty Minor Upanishads. Madras: np, 1914.

Audi, Robert. The Cambridge Dictionary of Philosophy. New York: Cambridge University Press, 2006.

Aurobindo, Sri. Essays Divine and Human. Pondicherry: Sri Aurobindo Ashram, 1996. nd. . The Synthesis of Yoga. Silver Lake: Lotus Light Publications,

Avalon, A. The Serpent Power. New York: Dover Publicatios, Inc., 1974.

Badudu, J.S. Kamus Kata-kata Serapan Asing dalam Bahasa Indonesia. Jakarta: Penerbit Buku Kompas, 2003.

Chatterji, Mohini M. (Transl.).Viveka-Cüdāmani or Crest-Jewel of Wisdom of Śrì Śamkarācārya. Adyar, Madras: The Theosophical Publishing House, 1983.

Dasgupta, S. A Study of Pātañjali. Delhi: Motilal Banarsidass, in association with Indian Council of Philosophical Research, 1989.

Eliade, Mircea. Yoga, Immortality and Freedom. Translated from the French by Willard R. Trask. Bollingen Series LVI. nc: Routledge \& Kegan Paul, 1973.

Feuerstein, Georg. The Yoga Tradition: Its History, Literature, Philosophy and Practice. New Delhi: Bhavana Books \& Prints, 2002.

The Yoga-Sūtras of Pātañjali: A New Translation and Commentary. Folkestone, Kent: Dawson \& Sons Ltd., 1979.

Gambhirananda, Swami (transl.). Eight Upanishads, with the Commentary of Śankarācārya. Volumes I-II. Calcutta: Advaita Ashrama, 1990, 1991.

Grimes, John. A Concise Dictionary of Indian Philosophy. Albany: State University New York Press, 1996.

Iyengar, K.R.S. Sri Aurobindo: A Biography and a History. Pondicherry: Sri Aurobindo International Centre of Education, 2006.

150 Georg Feuerstein, The Yoga Tradition, pp. 336-337. 
Jee, Lakshman S. Kashmir Shaivism: The Secret Supreme. Delhi: Sri Satguru Publications. A Division of Indian Books Centre, 1991.

Jesuit Scholars. Religious Hinduism: A Presentation and Appraisal. Allahabad: St. Paul Publications, 1968.

Klostermaier, Klaus. Hinduism: A Short Introduction. Oxford: Oneworld Publications, 2005.

Koelman, Gaspar M. Pätañjala Yoga, From Related Ego to Absolute Self. Poona: Papal Athenaeum, 1976.

Leaman, Oliver. Key Concepts in Eastern Philosophy. London \& New York: Routledge, 1999.

Madhavananda, Swami (Transl.). Minor Upanishads. Calcutta: Advaita Ashrama, 1988.

Mantra, Ide Bg. (penerj.). Bhagawad-Gìtā. Denpasar: Parisada Hindu Dharma Pusat, 1970.

Masih, Yakub. The Hindu Religious Thought (3000 B.C-200 A.D.). Delhi: Motilal Banarsidass, 1983.

Muni, Rajarshi S. Yoga: The Ultimate Attainment. Mumbai: Jaico Publishing House, 2004.

Nyanaponika. Buddhist Dictionary: Manual of Buddhist Terms and Doctrines. Kuala-Lumpur: Buddhist Missionary Society, 1998.

Nikhilananda, S. (Transl.). Vedānta-sāra or The Essence of Vedānta of Sadānanda Yogindra. Calcutta: Advaita Ashrama, 1987.

Pandit, M.P. Dictionary of Sri Aurobindo's Yoga. The United States of America Edition. Twin Lakes, WI: Lotus Light Publication, 2001.

Panjika \& N. Perawira. Kamus Baru Buddha Dhamma. Jakarta: Tri Sattva Budhist Centre, 1993.

Radhakrishnan, S. The Bhagavadgita. London: George Allen \& Unwin Ltd., 1953.

Radhakrishnan, S. (Transl. and Ed.). The Principal Upanishads. London: George Allen \& Unwin Ltd.; New York: Humanities Press Inc., 1969. Ltd., 1958.

Indian Philosophy. Volume II. London: George Allen \& Unwin

Rishabhchand. The Integral Yoga of Sri Aurobindo. Pondicherry: Sri Aurobindo Memorial Fund Society, 1974. 
Runes, Dagobert D. Dictionary of Philosophy. New Jersey: Littlefield, Adam \& Co., 1963.

Saraswathi, Ramanananda S. (Transl.). Tripura Rahasya or The Mystery Beyond The Trinity. Tiruvannamalai, India: T.N. Venkataraman of Sri Ramanasramam, 1989.

Satchidananda, Sri Swami (Transl.). The Yoga-Sūtras of Pātañjali. Yogaville, Virginia: Integral Yoga Publications, 2007.

Sharma, Arvind (Ed.). Our Religion. New York: HarperSanFrancisco. A Division of Harper Collins Publishers, 1993.

Swatmarama, Swami. Hatha Yoga Pradipika. Translated by Pancham Sinh. nc: Forgotten Books, 2008 (republished).

Taimni, I. K. (Transl.). Self-Realization Through Love (Nārada Bhakti-Sutra). Adyar, Madras: The Theosophical Publishing House, 1975.

. The Science of Yoga: The Yoga-Sütras of Pätañjali in Sanskrit with Transliteration in Roman, Translation and Commentary in English. Adyar, Madras: The Theosophical Publishing House, 1986.

. The Science of Yoga: The Yoga-Sütras of Pätañjali in Sanskrit with Transliteration in Roman, Translation and Commentary in English. Adyar, Madras: The Theosophical Publishing House, 1986.

Vasu, Rai Bahadur Shrisha Chandra. Gherandha Samhitā. Delhi: Book Faith India, 2000.

Vivekananda, Swami. The Complete Works of Swami Vivekananda: Mayawati Memorial Edition, Part II. Almora, Himalayas: Advaita Ashrama, 1932.

Wood, Ernest. Seven Schools of Yoga. (A Quest Book). Wheaton, Il.: The Theosophical Publishing House, 1973.

Yogendra, Jayadeva \& Clement J. Vaz (Eds.). Yoga Today. Madras-BombayCalcutta: The Macmillan Company of India Private Limited, 1971.

Zoetmulder, P.J. Old Javanese-English Dictionary. With collaboration of S.O. Robson. S-Gravenhage: Martinus Nijhoff, 1982. 